\title{
(息)
}

Citation:

Ross, SL (2014) Virtual money, practices and moral orders in Second Life. Distinktion: Scandinavian Journal of Social Theory, 15 (1). 6 - 22 . ISSN 1600-910X DOI: https://doi.org/10.1080/1600910X.2013.876435

Link to Leeds Beckett Repository record:

https://eprints.leedsbeckett.ac.uk/id/eprint/1337/

Document Version:

Article (Accepted Version)

The aim of the Leeds Beckett Repository is to provide open access to our research, as required by funder policies and permitted by publishers and copyright law.

The Leeds Beckett repository holds a wide range of publications, each of which has been checked for copyright and the relevant embargo period has been applied by the Research Services team.

We operate on a standard take-down policy. If you are the author or publisher of an output and you would like it removed from the repository, please contact us and we will investigate on a case-by-case basis.

Each thesis in the repository has been cleared where necessary by the author for third party copyright. If you would like a thesis to be removed from the repository or believe there is an issue with copyright, please contact us on openaccess@leedsbeckett.ac.uk and we will investigate on a case-by-case basis. 


\section{Virtual Money, Practices and Moral Orders in Second Life}

\section{Abstract}

Virtual monies present a limit case in debates about money's moral and political entanglements between

5 sociologists, anthropologists and economists. Digitised virtual monies seem ephemeral, almost ideal typical examples of money as a pure medium of exchange. This paper begins with premise that virtual monies are as value-laden and morally entangled as any other form of money. This assertion is demonstrated by exploring how one virtual money, the Linden dollar (L\$), and some of its associated practices, are bound up with research participants' moral categories and judgments in the virtual world of

10 Second Life (SL).

Participants' accounts of virtual money practices are linked to moral attributes, sometimes in stark 'good' or 'bad' dichotomies, but also in more nuanced terms. These framings reproduce classifications of people along a continuum with virtuousness at one end and malicious or harmful at the other, passing though

15 various states of possibly moral dubiousness. For respondents, these two judgments go together; people are what they do with money. As a result, respondents decide what 'people like that' deserve. Evaluating someone's money practices means assessing the person. Participants' accounts of Linden dollar practices overlap with explanations of what SL is and how residents should live there. In SL, money is a form of material culture through which appropriate ways of being in the world are debated and 20 reproduced.

\section{Abstract word count: 220}

\section{Body word count: 9192}

On November 5th 2007 I attended Metanomics, a weekly chat show in Second Life (SL) hosted by Robert Bloomfield, an economist from Cornell. The guest was Gene Yoon, then Vice President of Business Affairs at Linden Lab, the company that developed and maintains SL. The topic was 'Second Life's Economic Architecture'. Metanomics attendees are enthusiastic and well-informed, and the tone of 30 discussion is usually friendly, but this week would be different. Bloomfield began by asking whether Second Life's economy could be understood with traditional economic theories. Yoon replied:

... viewing what's going on in the virtual economy primarily through the lens of economics is a little bit of taking the metaphor too far. What we've got here in any particular element, say the Linden dollar, is a product. It's an element of what our 
offering is. And when we thought about how to put together the offering for the Linden dollar, it was more in the sense of a product team. We did retain economic consultants. But that was just one input. It was more trying to understand a particular product offering and not trying to understand the world of macroeconomics. (Metanomics, 2007:4)

When Yoon described Second Life's virtual money, the Linden dollar (L\$), as a product, many audience members typed angry replies in the Metanomics group chat channel. Such attendees thought Yoon's comment reduced Second Life to a mere service and Linden dollars to casino chips. Yoon and

45 Bloomfield struggled to continue their discussion in real-time voice chat over the rapidly scrolling lines of heated text-based debate. Audience members were still arguing about Linden dollars the following week, so Bloomfield asked his guests to comment on Yoon's remarks. For attendees, the discussion's terms had shifted; they were not only talking about what Linden dollars are, but how these monies should be used. Keel, a Metanomics audience regular, said in an interview: This [debate] isn't about what $L \$$ are anymore. This is about what some people do with $L \$$, and some of them are real bad.

For Keel, the moral status of virtual money practices and users merge. The words 'some of them' refer to people and money practices. For Keel, and other respondents, money practices are implicated in

55 producing and justifying moral orders in Second Life.

Economic sociologists and anthropologists have argued that money is not morally or politically neutral (Dodd 1994; Hart 2000; Zelizer 1997, 2005; Ingham 1996; Thrift and Leyshon 1997). Though sociological and anthropological critiques have defended the position that everyday monies are not mere

60 instruments whose only effect is making exchange and production more efficient, virtual monies seem somehow less consequential, more easily reduced to numbers or signs (see Thrift and Leyshon 1997 for a critique). Virtual monies are dematerialised, untainted by 'the social'. Yet virtual monies are still embedded in societies (Granovetter 1985). As Thrift and Leyshon (1997:20) argue, virtual money 'consists of a set of social practices like any other [money]'. Social practices, including virtual money 
65 practices, are entangled with moralities and assessments of others' respectability, social position, appropriate rights and dignity (Lamont 1992; Sayer 2005a, 2005b).

Virtual monies like the Linden dollar are not only implicated in moral judgments, they may also be moral entities. This paper extends existing debates on money's social entanglements into a new domain, virtual

70 worlds, using concepts from the sociology of morality. My secondary aim is a proof by example that economic sociology and the sociology of morality are an analytically useful combination deserving further exploration. Recently there has been renewed sociological interest in morality (Abend 2008; Hitlin and Vaisley 2010; Sayer 2005a, 2005b), but beyond Zelizer's $(1997,2005)$ work on families and intimacies, economic sociology has maintained an arm's length relationship with questions of economy and moral

75 order (Massengill and Reynolds 2010:486). Through an analysis of moral boundary drawing using virtual money practices in Second Life, this paper contributes to efforts in economic sociology and anthropology to elucidate - through empirically grounded examples - money's moral and political entanglements.

Without entering into debates about differing historical approaches to morality in sociology (see Abend 80 2008; Powell 2010) I follow Abend's (2008:87) conception:

The sociology of morality is the sociological investigation of the nature, causes, and consequences of people's ideas about the good and the right. . .

In this ethnographic research, respondents' descriptions of virtual money practices can be divided into

85 two broad types, according to whether interviewees emphasise either moral categorisation of practices, which are then projected onto people, or what people deserve based on how they use Linden dollars. In both instances, respondents draw moral boundaries between people with varyings degrees of respectability. These two kinds of accounts correspond to Abend's nature and consequences. Thus, my data and analysis primarily concern ideas and evaluations of practices rather than acts premised on

90 moral beliefs. The first type shows what beliefs exist about Linden dollars and how these ideas are used to generate and reproduce moral categories of people and practices. These are 'modes of reasoning and 
talking that define things as legitimate' (Wuthnow 1996:52). The second type are ideas about consequences that should follow for people engaging in certain practices.

95 Fourcade and Healy (2007:286) argue that theories and 'public justifications of contemporary economic order' - specifically markets - are 'intensely moralized and moralizing'. But not only markets are moralising. Dodd (1994:154) argues one of the key dimensions to a conceptualisation of money is its association with 'unfettered empowerment, of complete freedom'. Yet monies and moralities remain under-explored in sociology, except by proxy in studies of class (Lamont 1992; Sayer 2005a, 2005b). As

100 Hart (1986:638-639) has argued, 'money is at the same time an aspect of relations between persons and a thing detached from persons'. As things that are part of relations but also separate from them, monies are a means of distinguishing between people, things and relations. Monies are capable of performing the same tasks that moral boundary drawing (Lamont 2005a, 2005b) attempts to achieve. There is no higher virtue or moral duty in contemporary Western consumer capitalist societies than the injunction to

105 be free, to be empowered - though not always through consumption. It is difficult to imagine how any objects associated with such deeply felt, idealistic notions could possibly be morally neutral.

Finally, as 'places of human culture' (Boellstorff 2008:17), virtual worlds such as Second Life are spaces where moralities are generated, contested and maintained. Work on virtual moralities usually focuses on 110 griefing (eg: Bakioglu 2009, Luck 2009a) and cheating (eg: Wright et al 2002; Consalvo 2007). This paper moves into a new domain for virtual moralities by focusing on virtual economic activities. This paper contributes to a growing interest across interdisciplinary study of digital cultures in exploring moral distinctions that are not necessarily disruptive to user experiences or the flow of play in virtual worlds, such as ethics in romantic relationships (Gabriels 2012; Jones 2010); taboo violation (Whitty et al. 2011;

115 Luck 2009b; Young 2013). With respect to economies and moralities, there is small literature on real money trading in game-oriented virtual worlds (Nakamura 2009; Heeks 2009; Nardi and Kow 2010). However, Such research focuses more on racism and economic models than on moralities. 


\section{Methods and Field Site}

120 This paper draws on over three years of ethnographic research in Second Life conducted between 2007 and 2010, involving participant observation, informal discussions, open-ended qualitative interviews and analysis of secondary texts. This field work was part of a larger project on economic lay theories, categories and concepts. Participant observation included activities like creating objects with other residents; sociable activities like shopping, parties and treasure hunts; attending SL events (like

125 Metanomics), classes and academic lectures. Details of participant observation were noted in a field diary. With permission, screen shots (images) were also generated and archived. In addition to spontaneous, informal discussions, I conducted thirty one-on-one interviews in various settings: virtual homes and offices, landscaped gardens, shopping malls, underwater grottoes, and around campfires. Some interviews were multi-sited; respondents traveled through SL's virtual world, introducing me to

130 significant places and people. Interviews were conducted in English or French with respondents from Britain, France, Belgium, Italy, Spain, Holland, the United States, Canada, Russia, the Czech Republic, and Australia. Key informants quoted in this article are European and American. Interviews were automatically logged in the SL viewer client and then transferred to rich text files. Transcripts and participant observation notes were coded for shared and unique themes. For this paper, codes related to

135 moralities, monies, money practices and social exclusion were used. All names used are pseudonyms, with three exceptions. IntLibber Brautigan is a well-known Second Life businessman who preferred to be identified by his SL screen names to promote his virtual enterprises. Gene Yoon and Robert Bloomfield are public figures whose actual names are linked to their SL screen names. Secondary texts included forum posts, blogs, videos, press releases and materials suggested by respondents.

\section{About Second Life}

Second Life (SL) is a free-form, open source, three-dimensional virtual world created by its users, who are known as residents. This virtual world is accessed using software called the SL Viewer. Designed 
and maintained by Linden Lab, SL is home to a diverse range of communities. Respondents described

145 Second Life as a platform for creativity and sociability rather than a video game. Though each resident decides how she wishes to exist and interact in-world, conflicts can arise between competing visions of the virtual 'good life'. This article covers only one type of moral boundary drawing in SL - those related to money - but other significant distinctions exist. For example, moral boundaries are drawn around embodiment, as exemplified by some residents' unease with or aggression toward the animal bodies of

150 Furry residents (Bakioglu 2009:12-13). Moral boundaries are also drawn around behaviour toward new residents. Welcoming, helpful and generous attitudes are normative (Martin 2012; Boellstorff 2008:186187); behaving otherwise constitutes a moral failure according to some residents (Gabriels 2012:81).

Second Life's economy is interpenetrated by everyday economies. Linden dollars can be purchased with

155 everyday currencies, as in other sociability-oriented virtual worlds like There and Habbo Hotel.

Transactions between SL residents are paid in Linden dollars, and may occur in SL or through websites selling virtual merchandise. Linden Lab sells Linden dollars through their virtual money exchange (LindeX), and via a menu option in the SL viewer. There are third party Linden dollar exchanges, though not all are licensed by Linden Lab. Some residents are excluded from virtual money purchases because

160 Paypal or credit cards recognised by Linden Lab and third party Linden dollar sellers are not available in their country. An economically significant fault-line divides residents with a large stake in the promotion of Second Life's economy - land barons and business owners - from those whose consumption largely consists of freely copied and circulated goods (Boellstorff 2008:228).

\section{Theoretical Framework}

In Second Life, as in everyday communities, boundary drawing (Lamont 1992; Sayer 2005a, 2005b; Southerton 2002) links practices and values with individuals' or groups' placement in a community or society's moral order. Boundaries may be drawn based on any number of qualities, but amongst respondents money practices were used to distinguish the moral status of persons. Moral dimensions of 
170 monies in scholarly literatures are usually related to relations of structural domination (Dodd 1994; Hart 1986, 2000), or distinguishing between intimate social relations (Zelizer 1996, 1997, 2005), but this analysis explores how monies and virtual money practices are used to constitute and categorise moral subjects. Moral assessments also define the limits of communities, justifying opinions about who is deserving of what virtual rights and privileges. As Gumbard (2004:169) argues, 'symbolic and structural

175 properties of money reveal complex cultural logics'. Moral boundary drawing through money practices reveals regimes of worth (Boltanski and Thévenot 2006) and hierarchies of value and disgust. Weber ([1930]2001), Simmel ([1907]1978:218) and Marx ([1867]1906) linked monies with moralities in their accounts of 19th century capitalism (Powell 2010 and Abend 2008), and this tradition continues in Zelizer's $(1996,1997,2005)$ work on earmarking and Dodd's (1994) and Hart's $(1986,2000)$ emphasis

180 on money and social inequalities. Yet what has been missing in economic sociology are concepts that explain how monies - or other economic categories - produce and maintain moral orders.

Zelizer (1996:484) argues that earmarking creates 'a multiplicity of socially meaningful currencies' that are used to sort and categorise relations. However, her accounts of poor relief by American charitable 185 organisations (Zelizer 1996:485; 1997:145-160) suggest monies and money practices sort people as well as relations.

... the managerial incompetence of the poor provided a perfect loophole to justify the active intervention of social workers in the domestic economy of their clients. For despite new environmental theories of poverty, it was still simpler to redo private economies than tamper with the public market. (Zelizer 1997:152)

Perceived improvident money use - 'irresponsible' money practices - justified paternalistic interference in the lives of impoverished people, particularly immigrants (Levenstein 2003). A category of people was identified through their 'bad' money practices. This new group was then precluded from exercising

195 economic agency, ostensibly for their own good. Moral judgments of how money is used thus justify an abject place for a category of persons constructed through and identified by money practices. This example of boundary drawing between the fiscally responsible and feckless is echoed in respondents' 
accounts of money use in SL.

200 Boundary drawing 'on the basis of moral character' (Lamont 1992:5) classifies people according to their perceived merit according to their practices, appearance or other characteristics. By inferring a person's qualities from those associated with their observable (or imputed) practices, boundaries can be drawn separating degrees of respectability and disgust.

... social groups often distinguish themselves from others in terms of moral differences, claiming for themselves certain virtues which others are held to lack: we are down-toearth, they are pretentious; we are cosmopolitan, they are parochial; we are hardworking, they are lazy, and so on ... while the possession of the claimed virtues is held to be localized, the valued norms themselves are assumed to be universally applicable. (Sayer 2005a:953)

For Sayer (2005a, 2005b), these boundaries are part of the reproduction of social class in England. For respondents, class is less relevant than distinctions between land owners and 'homeless' users, as Boellstorff (2008:99) also notes; or between residents who buy Linden dollars and those who do not (or between those who are financially or technologically able to purchase virtual money and those who 215 cannot); or between earners and buyers of Linden dollars.

Moralities are ways of differentiating between, and speaking or thinking about what is good, right and legitimate, and what is bad, wrong and illegitimate. In participants' accounts, what people do very quickly slips into descriptions of who and what people are, and what they deserve. Being deemed unworthy

220 includes separating those who may participate in communities from those who may not, and devaluing those whose participatory rights are limited or denied. These symbolic boundaries

... presuppose inclusion and exclusion and are constructed through the social practices, attitudes or values that are affirmed and re-affirmed through interaction. (Southerton 2002:175)

The scale of inclusion and exclusion varies. Exclusionary rhetorics such as the false dichotomy of 'strivers and skivers' in Britain links failure to participate in 'good' money practices - savings, financial 
services, debt accumulated through property ownership - to further marginalised unemployed or disabled people, students and workers in precarious employment. How money is used becomes a kind of

230 citizenship test whose results must be re-affirmed repeatedly by remaining solvent, being credit worthy (Polillo 2011), and spending money appropriately (Gumbard 2004). These shared understandings build a polity that 'sustains various constructions of political philosophy and gives direction to the ordinary sense of what is just' (Boltanski and Thévenot 2006:74). Such agreements about what is worthy and proper, which are admittedly rather fragmented in virtual worlds (Ross forthcoming), establish the principles of a

235 shared humanity. With respect to money, such understandings 'reflect in microcosm the larger social world' (Gumbard 2004:169), as money is both embedded in and separate from social relations.

The consequences of classifying people according to the moral status of their money practices according rights to some and taking them away from others - strike at the essential nature of money. Money. . . is not defined by its properties as a material object but by symbolic qualities generically linked to the ideal of unfettered empowerment. . complete freedom to act and assimilate at will, is none the less at the heart of the conceptualization of money in general as a transparent symbolic medium. This is the basis of the desire to possess money, of the very concept of money. . (Dodd 1994:154)

In consumer capitalist societies especially, money is deeply linked to emancipation and 'empowerment'. Monetary accumulation in particular has social and economic benefits. Simmel ([1907]1978:218) describes the deference and privileges accorded a person believed to possess great sums of money as an 'unearned increment of wealth'. Yet through rhetorics and practices of social exclusion predicated on

250 moral boundary drawing money practices can be used to disempower. Such uses of monies and money practices are the other side of the coin, as Hart (1986) suggests to images of money as freedom.

Ordinary understandings of moral order that are related to monies and money practices help explain and justify unequal distributions of wealth - as in the example of strivers and skivers discourse - which are already understood as moral and social problems in economic sociology and anthropology. 


\section{Money Practices and Moral Orders}

Creativity as virtue and self-fulfillment are central to many residents' understanding of SL (Boellstorff 2008:31), and were linked with boundary work ordering people according to their moral status using money practices. Many respondents linked the virtues of creativity and labour as self-fulfillment with

260 saving and earning Linden dollars. This perspective combines modern Western rational capitalism (Weber [1930]2001:27-28) with creationist capitalism (Boellstorff 2008:206), a moral order based on the virtues of work, frugality and creativity. This polity of 'virtuous' users contribute to SL's economy by saving virtual money, creating new commodities, and investing in entrepreneurship, unlike an imagined group of ostensibly less worthy residents who purchase Linden dollars with everyday monies and only

265 consume. In this view earning and saving are better than conversion, but buying Linden dollars is a multivalent practice. Others respondents position conversion as neutral or even as a moral duty. For such interviewees, spending virtual money becomes a virtuous practice, a kind of basic civic participation. Distinctions between money practices define which values and activities constitute a 'good' Second Life, and order people along multiple moral spectra. The ease with which respondents transition between classifying virtual money practices and categorising people indicates moral boundary drawing in action. Virtual money practices and the moral status of people are mutually constituting.

Vivian Tei owns an SL haberdashery and clothing shop. Vivian prizes virtual craft skills, imagination and entrepreneurship; she describes her leisure-labour as 'a creative, fulfilling project'. For her, creativity is

275 central to SL, and money earned through virtual work is a special reward. I spoke with Vivian while she was redecorating her newly expanded boutique.

Vivian: all of my money comes from my item sales. I buy very little and have a high quality standard, so I end up saving up a lot, which is good because it gives me money for more land later on.'

Vivan emphasises that her money flows from productive labour and innovative designs. This is the essence of creationist capitalism, 'in which labour is understood in terms of creativity, so that production is understood to be creation' (Boellstorff 2008:206). Vivian positions saving as an aesthetic and moral 
choice. Few objects meet her craftsmanship standards, so she refrains from spending. Savings must be

285 used responsibly for business expansion; Vivian's first profits paid for an SL class on making interactive, customisable clothes. In this view, saving and reinvesting are not just money practices, they are virtuous acts. Vivian's beliefs echo the spirit of capitalism Weber ([1930]2001:13-16) identifies in Benjamin Franklin's writings. An entrepreneur has a moral duty 'toward the increase of his capital, which is assumed as an end in itself' (Weber [1930]2001:16).

290

Vivian identified earning, saving, reinvestment as associated with virtues of frugality, enlarging capital and creation. She then drew moral boundaries between creators and residents who purchase Linden dollars.

Vivian: As for people using their real world assets, most people who start a business already do, be it $\$ 50$ to cover buying the shop land or putting in some extra for front page listings on SL. Even if they put a large amount of money into it, it won't buy them skill or creativity, though they could hire people. However, there will still be many more talented people...

300 Shop owners who purchase Linden dollars buy their way into being an entrepreneur rather than slowly building up a business. If a new resident, as identified by the virtual birth date in their SL profile, converts capital to open a shop, Vivian sees this as spending money without appreciating its value.i Such residents may be business owners, but they are not, in Vivian's eyes, valued members of Second Life's esteemed communities of makers, artists and builders. Vivian uses money practices - conversion versus

305 accumulation and reinvestment - to create a moral boundary between consumers and creators. Entrepreneurs are accorded social recognition as economic and intellectual contributors in a usercreated world. Creators' virtuous money practices that build a virtual enterprise slowly are distinguished from those of residents who buy the trappings of being a business owner with converted capital from everyday life. For Vivian, conversion of economic capital from everyday life into Linden dollars is morally 310 contaminating; even virtual money may stink. In her view, converted money is 'neither earned nor deserved'. Vivian says, 'buying $L \$$ is a necessary evil because some people don't make anything to sell 
or trade'. Yet she places her highest moral goods - 'skill or creativity' - beyond the reach of money. Entrepreneurs who buy Linden dollars can only buy others' labour, not the coveted status of being a creative person.

Billie-Jo Pawnee, a virtual sex worker, also links the moral status of residents to how their money is acquired.

SR: Are lindens received through work, or camping different from lindens someone buys?

Billie-Jo: yeah. i think they are. if you get them inworld [sic] it doesn't matter on what you spend it, but if you buy them, you're putting R[eal] L[ife] money in a virtual world, just pictures. It doesn't mean anything. That's crazy.

For Billie-Jo, virtual work and camping - earning tiny sums of Linden dollars for remaining in a particular 325 place in SL for hours ${ }^{\mathrm{iii}}$ - are moral equivalents. She continued:

It doesn't matter how you get L\$ in SL. Escorting [sex work] is easier than making stuff. Camping is annoying, but it's all the same as long as you don't throw RL money down the toilet.

330 Virtual money accumulated in SL can be frittered away on 'pictures', but buying Linden dollars to spend on virtual goods is 'crazy'. Talk about money practices slips swiftly into evaluations of people based on how they use money, and conversion is again positioned as a sign of degeneracy. 'Crazy' people throw away money, whereas people with sound (economic) judgment spend money appropriately. Like Vivian, Billie-Jo differentiates between earning and buying Linden dollars, but she does not link creative work

335 with virtue, though she suggests creative work is difficult. Instead, she suggests a moral ordering based on 'wise' consumption. Virtuous saving means accumulating everyday monies and not spending them to purchase digital, virtual goods only accessible in SL. Ally, a London-based visual artist, agrees: 'people who buy L\$, they need their heads examined!' In this view, Linden dollar buyers exchange money that purchases useful, needful goods for virtual money that only buys 'pictures'. Ally and Billie-Jo suggest that people who purchase Linden dollars fail to internalise appropriate standards of economic value in which actual currencies are for purchasing tangible, durable commodities, not virtual monies. This association 
between money conversion and mental illness draws a strong moral boundary separating mentally and fiscally competent actors from those who are putatively incompetent in both respects.

345 Julie Walker is an American white-collar worker for whom spending is virtuous, and conversion is routine. For Julie, living a good Second Life is an aesthetic, sociable experience: 'SL is express[ing] what I like, to look hot \& meet other good-looking people!' Julie's emphasis on avatar attractiveness is not atypical (Kaplan and Haenlein 2009; Gottschalk 2010). She buys about \$15 USD in Lindens dollars monthly. When asked to comment on debates about Linden dollars arising from Gene Yoon's remarks on Metanomics, Julie transitions quickly from talking about money to explaining how money should be acquired and used.

Julie: $L \$$ is not real Julie: when it [ $L \$$ balance] gets low, i buy more Julie: that']s why its not real SR: Where do your Lindens come from? Julie: um i buy them thru the menu SR: So, clicking on the Buy L\$ [menu] option? Julie: yah is there sum other way Julie: like camping SR: well, you could be camper, or buy from the LindeX? Julie: camping is boring. $u$ sit \& sit \& sit Julie: also yuck! so gross!!! all blingy clothes, bad skins, ugly face lights SR: So you wouldn't want to camp for money or items? Julie: no way. not fun ppl. campers don[']t chat or they talk dum[b] stuff Julie: getting $L \$$ that way is for stupid ppl Julie: better to buy $L \$$ Julie: that[']s the good way SR: Why is it better to buy $L \$$ than get them some other way, like LindeX or camping? Julie: [SL] shops could sell more things with less camp chairs \& mats Julie: freebies $r$ ugly!!!

For Julie, the Linden dollar is 'not real' because when she has none left it is possible to simply 'get more'. Like Vivian, Julie believes actual money is earned, not bought, but in her view buying virtual money confers no moral taint. For Julie, like Gene Yoon, Linden dollars are part of a bigger product: Second 
375 Life.

Though Julie's understanding of the Linden dollar comes closest to the neutrality and efficiency of economic theories - money is a mere means of effectuating exchanges - she also uses money practices to evaluate other residents. Julie responds negatively to camping, showing visceral disgust toward those

380 who camp and consume free goods. She slips between identifying commodities as ugly and labeling people as unattractive or inferior. Campers are morally and socially repugnant because of their unwillingness (or inability) to convert everyday monies into virtual funds. There are other explanations for quietness and camping: language differences; being away from the computer; limited access to online payment methods; or being uninterested in virtual shopping. These negative qualities may not even be

385 an accurate characterisation of users who do not buy Linden dollars, yet Julie connects all these 'failings' to money practices. Julie's position was not anomalous amongst respondents, though such perspectives are not well represented in academic literatures on SL which tend to emphasise more inclusive attitudes (Martin 2012; Martey and Consalvo 2011; Beollstorff 2008:100)

390 Julie compares residents who fail her standards of decency with those who do Second Life in a 'good way'. Proper participation in SL means purchasing Linden dollars to buying high quality digital virtual goods and creating attractive self-presentations. Doing SL correctly also includes being 'fun' and friendly with others, but Julie links this explicitly with spending money. Freebies in SL are distributed using the same scripts, or mechanisms, as commodities that cost virtual money. The process of acquisition is the

395 same: point, click and confirm to generate a copy of the item in the user's inventory. The only difference is the price: $\mathrm{OL} \$$. The pleasures of shopping - browsing goods, selecting, acquiring and enjoying new things - can be enjoyed even without Linden dollars when purchasing goods with a price of OL\$.

Shopping and consumption are no longer distinctive virtual money practices when free goods are being distributed alongside commodities sold for $1 \mathrm{~L} \$$ or more, which means these practices are not helpful in 400 distinguishing residents from one another. Nearly every resident engages in some form of shopping at 
some point in their engagement with SL, even if the items they buy are free. Instead of shopping practices that residents without virtual money may also perform, Julie uses conversion and expenditure to distinguish between decent residents like herself who are spending money (both virtual and actual), and people who are not participating appropriately because they are not spending money. In this view,

405 expenditure and recirculation of money are virtuous practices rather than creative labour or savings. This is an ethic of expenditure in which those who spend are 'participating' and those who do not are failing in a moral duty to recirculate money. Julie blends aspects of Boltanski and Thévenot's (2006:178-179, 195-198) world of public opinion and market world, with her emphasis on beauty and appearance on the one hand, and being a desiring subject, and spending money on the other. Julie does not fits into either

410 category, and a mixture of the two fails to do justice to her moral schema or the conceptual work of Boltanski and Thévenot (2006).

$\mathrm{PD}$, an aspiring land baron who owned several islands, also believes that spending and conversion are central to doing SL properly. Julie only suggested shops could sell more merchandise without campers,

415 whereas PD argues SL would be improved by removing residents who do not use virtual money. We spoke at his nightclub, whilst he was redecorating and queuing music for a party.

PD: linden [lab] should tomorrow clean the grid. clean up $50 \%$ of the land and force people to go premium. that will be a natural selection.

420 PD's believes residents who do not buy Linden dollars are the 'biggest problem' in SL: 'if ya dont want to work for ya money then better stay home in R[eal] L[ife] or leave SL!' PD describes such residents as 'lazy', echoing comments made off the record by other entrepreneurs. From this perspective, conversion is a moral imperative. Residents who do not buy Linden dollars, or earn them through some form of virtual work, are not properly participating in SL. When PD suggest that free SL user accounts should be 425 'destroyed' and 'p[eo]pl[e] who do not contribute to the economy' should be 'exterminated' or forced to switch to a fee-paying, premium account, he moves beyond associating money practices with moral or normative beliefs. Words like 'exterminated' or 'destroyed' replace usual computer-related terminology 
such as deleted, deactivated or removed. Such terms emphasise that PD is talking about poorly disciplined subjects requiring punishment, who he describes as a 'cancer killing SL'. PD's aggressive

430 language links money practices to normative standards then places people into two categories: those who should continue to enjoy SL, and those who should not be permitted to do so. Money practices sort people into those who have a right to exist in Second Life, and those who do not.

\section{Participation, What People 'Deserve' and Prefigurative Politics}

435 Respondents draw boundaries separating residents like themselves, with similar, ostensibly legitimate money practices and associated moral values, from residents whose dodgy or even harmful money practices are evidence of moral failings or inferiority. For most research participants, engaging in certain money practices does or should limit the scope of practitioners' participation in SL. Whilst theft of Linden dollars was widely agreed to be wrong (see also Gabriels 2012), most of practices respondents

440 identified as problematic were more mundane: conversion, spending, accumulation, investment, or development and use of virtual financial instruments. Some interviewees argued that residents who do not convert and spend money should be warned to change their behaviour or, echoing PD, should be exiled from SL. Other participants suggested the introduction of new money practices associated with virtual high finance are laying groundwork for what residents - or in broader framings, humankind -

445 deserve. In this view, it is not other residents' questionable money practices so much as Linden Lab's minimal regulation of SL that is perceived to obstruct not only the just deserts of the economically righteous, but their desired ways of participating in the virtual world. Virtual money practices become prefigurative politics producing a techno-utopian future.

450 Hanna Gimble produces scripted objects, clothes and accessories for Furries, people who 'identify with, and may wish to assume, characteristics of nonhuman animals ' (Gerbasi et al., 2008:198). Furry residents have their own well-established subcultures in SL (Boellstorff 2008:185; Bakioglu 2009). Hanna's creations are sold on consignment in a Furry role-playing area. For her, spending Linden dollars 
is how residents should express appreciation for and engagement with virtual communities.

Hanna: the $L \$$ is like voting. Spending on something means you want more of it. ie: buying furry av[atar]s is a way to show that you're part of [a] furry community. Making things is also good, but it[']s not very friendly to make stuff only for yourself. $[\ldots]$

SR: So what would you say to people who don't buy $L \$$ ? Hanna: Please stop hurting SL. Even if you can just buy only a small amount of $L \$$, and only buy a few things, or become an entrepreneur. Get involved. SL is evolving all the time. Getting better when people work together. But not when people don't invest in it. SR: What about people who don't spend L\$?

Hanna: it's sad, but they should stop being here. SL is special, we need everybody to contribute. just find some other place to go.

Hanna's shopping as voting comparison transforms consumption into ethical, political action. Her remarks echo campaigns in everyday life that encourage purchase of FairTrade, organic and other socially-conscious products (Micheletti 2003). For Hanna, residents have moral duties to build SL's economy through virtual money use, while shops - as markets for goods - serve as sites where social and moral sensibilities are generated, reproduced maintained (Detlev et al 2007:187-189).

Spending money signals desired content, which changes the unfolding creation of SL. Virtual money practices blend participation and creation in a dialectical process. For Hanna, conversion and spending

475 are tied to maintaining virtual communities, and those who are not spending are not participating properly. Social ties are not sufficient measures of group membership; residents must also provide economic support by recirculating Linden dollars, producing or selling virtual commodities. Hanna too is a creationist capitalist (Boellstorff 2008:206). This emphasis on spending as an ethical requirement is influenced by Hanna's everyday life in SL, which revolves around a Furry role-playing group that owns several large plots of virtual land. Group members contribute small sums to meet Linden Lab's monthly service charges. Hanna's contributions come from money she earns through consignment sales and her own purchases of Linden dollars. 
Like PD, Hanna also thinks residents who are not 'invest[ing]' economically should depart. Instead of

485 beginning by drawing a firm moral boundary between those who are 'hurting SL' and those whose efforts improve the virtual world, she first makes a plea for improved behaviour. Her stress on contributions, and the need for residents to 'work together', suggests that participation should be contingent upon appropriate economic comportment. In this view, like that of PD, virtual existence and community participation are privileges that must be earned and maintained by bringing money into $S L$ and recirculating it. Hanna's words for ostensibly non-contributing residents are less violent than PD's, but the underlying logic remains the same: economic non-participation is a moral failure justifying social exclusion.

IntLibber Brautigan was a virtual financier, entrepreneur and outspoken critic of Linden Lab; he is no 495 longer an SL resident. In two interviews, IntLibber expressed concerns that economically virtuous (and industrious) users whose money practices build SL's economy, were being deprived of their deserved rewards, such as esteem, recognition and capital investment from business communities in the actual world. Like Vivian, IntLibber's moral ordering blend of Weber's ([1930]2001:13-16) spirit of capitalism and Boellstorff's (2008:206) creationist capitalism, but unlike Vivian, he suggests that earned rewards

500 are not being received. This situation arises because the practices in question are devalued by powerful others, specifically Linden Lab. As a Metanomics guest, IntLibber commented on Gene Yoon's controversial remarks:

I don't see it [Second Life] as a game. I don't see the Linden dollar as a fiction or a license. . . I find these kinds of statements [like Gene Yoon's] as really disingenuous evasions, and I'm not sure why these people [Linden Lab] are doing this. . . (Metanomics, 2007b:26-27)

For IntLibber, reduction of the Linden dollar to a product adds insult to injury. Linden Lab's policies and public statements devalue his virtual money practices and those of other SL entrepreneurs, preventing 510 recognition for their business achievements. In an interview at the Ancapistan Capital Exchange (ACE), a virtual stock exchange he founded in SL, IntLibber elaborated on this theme. 
IntLibber: the stigma [against SL business] really is because we were founded INSIDE the 'game', and because we are not ivy leaguers with lots of corporate contacts and trust fund backers. the fact that a person can make their living inside SL should be seen as a really impressive achievement, especially given the economy of micropayments here. that[']s another issue. the $L \$$, which $L L$ insists is a fiction, a licensed service. they [Linden Lab] damage the credibility of their claims of SL being a 'business platform' by claiming the $L \$$ isn't money. It[']s paradoxical. If it[']s not money then SL can never be a business platform, and real life businesses know that.

Associating virtual businesses with a space of leisure diminishes the respectability of SL entrepreneurs. Financial practices using virtual money like investment, raising capital through initial public offerings on SL's stock exchanges, virtual book keeping and creating virtual financial instruments become inconsequential play rather than innovative e-commerce. Presenting Linden dollars as a service rather

525 than as money fosters what IntLibber calls a 'stigma' against virtual entrepreneurs. Goffman (1963:1213) describes stigma as 'deeply discrediting' devaluing of a person in others' eyes. In this case, SL business communities are being delegitimised and trivialised by Linden Lab, reducing their capacity to engage with business communities outside the virtual world. The utopian future IntLibber and his associates are trying to build through their virtual money practices is being pre-empted by fiat.

As a self-described libertarian and transhumanist, IntLibber believes building grassroots financial infrastructures for residents is a form of political action enabled by Linden dollars. His efforts to promote virtual finance are the beginning of what he calls 'the next stage of the Internet'. In IntLibber's view, a wider range of money practices provides residents with a constantly-evolving, self-regulating and self-

535 governing economy that is not reliant upon Linden Lab, and this is the economy that SL's productive, creative residents deserve. He describes this ideal as an 'economic Singularity'. For transhumanists, the Singularity is the birth of an emergent artificial intelligence (Kurzweil, 2006), an event with distinct messianic overtones. IntLibber's concept of an economic Singularity blends libertarian capitalism with transhumanism's utopian vision of human transcendence through technology. ${ }^{\text {iv }}$ Through these new 540 virtual money practices, residents can continue working toward a future Second Life, or other virtual 
world where the economic Singularity may appear. Rather than looking busy because the Messiah is coming, as the old atheist joke suggests, adherents to this anarcho-capitalist, transhumanist utopian vision are producing a digital messiah, the economic Singularity, through their busyness/business. ${ }^{v}$ Like Weber's ([1930]2001:36-37) Protestant business owners, salvation may be achieved through devotion to

545 a (virtual) worldly calling. More than being 'a, or rather the, task set by God' (Weber [1903]2001:45), virtual money practices are activities that create an emergent messianic entity.

Like IntLibber, B.Bach too envisions a techno-utopian future achieved through virtual money practices. An early adopter of SL, B.Bach uses non-gendered avatars, such as clouds and trees. It has been a

550 virtual shop owner, land lord and coder, but is now primarily a teacher, organising building and scripting classes. For B.Bach, the Linden dollar is an emancipatory technology, an unquestionable moral good that makes the future.

B.Bach: $S L$ is just the start. $L \$$ are the future of everything: real, digital, virtual. We[']re layin out foundations here for the future. $L \$$ are a big part of that. Money thats real and in this virtual world we use it to make, buy, sell stuff. people, stuff they get together with $\mathrm{L} \$$. its making life here. in the future, we'll all be livin here, in cyberspace. be what you want. do what you want. live like you want. freedom. [The] L\$ makes it happen. all these links.

SR: What links?

560 B.Bach: its like pe[o]ple online \& all doin things because we got this L\$. some euro[pean] folks they get stuff made by chinese guys, \& chinese guys get stuff I make. hows that for equalizin trade defecits [sic]!!

B.Bach: the futures here. soon avvies [SL users] will buy offline stuff in SL. 3d prints at home. SL stuff wont be just virtual. other v[irtual] w[orld]s will come but they [will] all build off SL. then next we[']ll leave that [offline world], go in here \& stay. everything will be virtual digital. thats the future.

B.Bach: all this happens w/L\$. thats why $S L$ is not like other vws. its real. $L \$$ makes SL's economy real. buy sell land banks investin. even stocks. not all thats good stuff but its the start. $\mathrm{L} \$$ makes all equal. anyone can get it. $\mathrm{L} \$$ is not GDP or big corp[oration]s. its money for sharing. not profits. it helps pe[o]ple live together. no more gover[n]ment. no more war. people all peacefully in communities. cooperation.

In B.Bach's view, Linden dollars can usher in an emancipated, digital future that leaves human bodies 
behind, culminating with living harmoniously in cyberspace. The Linden dollar is an essential stage in

575 B.Bach's imagined future, allowing people to take up residence in virtual worlds by buying land, accumulating goods and building virtual lives. For it, the Linden dollar enables commerce and connections across geo-political boundaries and language barriers, it connects people. The Linden dollar is also a utopian money - 'for sharing' not for profiteering - available to everyone that constructs communities. IntLibber imagines an emergent intelligence arising from an economy with a wide range of

580 money practices and forms, a libertarian, anarcho-capitalist paradise. B.Bach dreams of a world that will be drawn together by Linden dollars, a world that is no less associated with individual emancipation as IntLibber's vision, but is organised through shared community life, rather than an artificial intelligence operating as both Prime Mover and invisible hand.

\section{Conclusion}

I attempted in this paper to show how a virtual money - the Linden dollar - and some virtual money practices are entangled with moralities through their use in boundary drawing within Second Life. In doing so, I hoped to achieve two additional aims, to extend analyses of money's entanglements with moralities and moral order into a new domain, virtual economies, and to show that concepts from the

590 sociology of morality can be used in economic sociology to think about under-examined connections between monies - both virtual and actual - moral orders, practices and economic life. Respondents associated virtual money practices with moral values, drawing boundaries separating those with 'proper' economic subjectivities from residents whose practices are less desirable. Slippage between evaluating money practices and making moral judgments about people was routine amongst interviewees,

595 demonstrating very ambiguous boundaries between assessments of practices and of people. In Second Life, virtual money is not only used to sort social relations - as Zelizer (1997) argues with respect to the United States dollar - it is also about sorting people into moral orderings based on perceived worth and dignity. These classifications have normative elements, as participants believe certain rights, duties or punishments should accrue to other residents as a result of their virtual money practices. When poor 
600 virtual money practices become failed economic citizenship, some respondents argued that the very right to exist in Second Life should be denied. It is difficult to ignore parallels between these ways of thinking and exclusionary rhetorics tied to economic practices that have become practically commonplace in Anglo-Saxon countries and within some countries of the European Union, especially since the start of the financial crisis.

605

The moral orderings that informed respondents judgments suggest more work is needed on connections between values and moralities with respect to economic life. Vivian Tei's moral schemata blended Second Life's creationist capitalism (Boellstorff 2008:206) and a digital virtual update of Weber's ([1930]2001) Protestant work ethic, but other combinations were less familiar. Julie Walker's and

610 IntLibber's moral boundary drawing mix regimes of worth (Boltanski and Thévenot 2006) to create familiar yet strange hierarchies of values. These moral orders are not bizarre, yet they do not fit very well into established categories, illustrating an analytical and conceptual poverty that lies at the heart of economic sociology. Research on economic moralities could expand economic sociology's narrow conception of 'the social'. Social embeddedness is often limited to social ties - family, work ties and inter-

615 firm connections (Granovetter 1985). Moralities, moral orders and politics - both institutionalised and personal - are ways of relating to and with others that have economic dimensions in which monies, markets and value(s) are called upon to explain normative practices, justify judgments and classifications. There is also a general need for better understanding of lay theories of economic life, like those explored in this paper, to fill gaps between well-established literatures in economic sociology on

620 financial elites on the one hand, and portraits of intimate domestic lives and the family on the other.

Moral entanglements are likely not anomalous amongst virtual monies. Other sociability-oriented virtual worlds have fungible virtual monies, but their moral dimensions remain unexplored. An industry has formed around real money trading (RMT), or gold farming, in massively multi-player online role-playing 625 games like Final Fantasy XI, Guild Wars 2, World of Warcraft and Age of Conan, allowing players to 
purchase even ostensibly non-convertible virtual monies. Except by proxy through racist categorisations (Nakamura 2009), research on RMT has not explored moralities, instead focusing on economic models (Heek 2009; Castronova 2006). Further work is needed on how virtual money practices, and virtual monies themselves, are implicated in generating local moralities.

When virtual monies and practices are used to classify people and make judgments about what rights certain groups of people 'deserve' as scholars we must also ask about the role of monies and money practices in shaping politics. Perceived or desired consequences of virtual money moralities were articulated as normative prescriptions about rights and types of participation accruing to people

635 according to their money practices. Some participants even argued that full economic engagement is a prerequisite for the right to exist in SL. Exclusionary views like those of PD and Hanna were not anomalous in this research, but such perspectives are underrepresented in academic literatures on Second Life. Whether respondents behave in ways that are consistent with their moral orderings of people and practices was beyond the remit of this paper, which focused on the nature and perceived consequences of moral beliefs rather than how respondents act on them. Some views expressed by participants are observable as absences rather than acts, such as avoiding or ignoring residents with unattractive avatars (Kaplan and Haenlein 2009; Gottschalk 2010; Banakou and Chorianopolous 2010); or refraining from providing free goods in their shops, as Vivian Tei does; or banning camping from their land, as PD does. Social desirability bias and norms of friendliness and generosity in SL also mitigate

645 against public displays of discrimination that would be compatible with such beliefs. Such firm, negative boundary drawing raises questions about underrepresented voices in academic literatures, which tend to present SL as a friendly place with a large gift economy and normalised generosity toward new residents. These notions are accurate, but there are also other views about Second Life, like those of Hanna, PD, IntLibber and other respondents who expressed discriminatory views about certain 650 perceived types of residents. There is a need for more critical distance in research on SL so perspectives like these can be heard. This is not because we condone discrimination or have some 
dislike of virtual worlds as scholars, but because such beliefs offer important insights not only about SL but also about everyday life. Boellstorff's (2008:145) observations about hegemonic whiteness, and Dumitrica and Gaden's (2008) concerns about hypersexualisation and gender in SL are examples of

655 such alternative perspectives. In this paper I was not concerned with moralities in practice, but rather respondents' moral conceptions and what they believe should occur. However, having established that virtual monies are implicated in moral boundary drawing and classifications, the next step in a continuing research programme is to explore economic moralities in action, in SL, other virtual worlds and everyday life.

660

\section{Acknowledgements}

I am grateful to Keith Hart, who encouraged preparing these materials for publication in 2011. This paper expands on part of a dissertation chapter that benefited from Nigel Dodd's money expertise and Don Slater's insights on Second Life. Constructive and thoughtful feedback from peer reviewers was very

665 helpful, as was support from Distinktion editors. Special thanks also to Reuben Flores, who sent me the call for papers for this special issue.

\section{References}

Abend, G. 2008. 'Two Main Problems in the Sociology of Morality.' Theory and Society. 37(2):87-125.

Bakioglu, B. 2009. 'Spectacular Interventions in Second Life.' Journal of Virtual Worlds Research 1(3):121.

Banakou, D and Chorianopolous, K. 2010. 'The effects of avatar gender and appearance on social 675 behaviour in virtual worlds.' Journal of Virtual Worlds Research. 2(5):4-16.

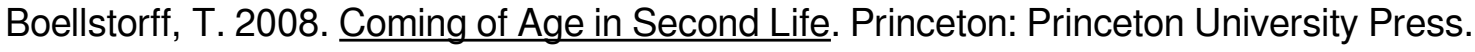

Boltanski, L and Thévenot, L. 2006. On Justification. Princeton: Princeton University Press. 680

Bourdieu, P. 2010. Distinction: A Social Critique of the Judgement of Taste. London: Routledge.

Castronova, E. 2006. 'A cost-benefit analysis of real-money trade in the products of synthetic economies.' Info. (8)6:51-68. 
Consalvo, M. 2007. Cheating: Gaining Advantage in Video Games. Cambridge: MIT Press.

Dodd, N. 1994. The Sociology of Money. Cambridge: Polity Press.

690 Dumitrica, D and Gaden, E. 2008. 'Knee-High Boots and Six-Pack Abs: Autoethnographic Reflections on Gender and Technology in Second Life.' Journal of Virtual Worlds Research. 1(3):3-23.

Fourcade, M. and Healy, K. 2007. 'Moral Views of Market Society.' Annual Review of Sociology. 33:285311.

695

Gabriels, K. 2012. '“Virtual Morality”: The Un/Acceptability of Hypothetical Scenarios in Second Life.' Proceedings of the SL Actions 2012 International Conference. pp.75-101.

Gerbasi, K, Bernstein, P, Conway S, Scalettad, L, Priviterae, A, Paolonef, N and Higner, J. 2008. 'Furries

700 from A to Z (Anthropomorphism to Zoomorphism).' Society and Animals. 16(3):197-222.

Goffman, E. 1963. Stigma: Notes on the Management of Spoiled Identity. London: Penguin.

Gottschalk, S. 2010. 'The Presentation of Avatars in Second Life.' Symbolic Interaction. 33(4):501-525. 705

Granovetter, M. 1985. 'Economic Action and Social Structure: The Problem of Embeddedness.' The American Journal of Sociology. 91(3):481-510.

Gumbard, M. 2004. 'Money that burns like oil: A Sri Lankan cultural logic of morality and agency.'

710 Ethnology. 43(2):167-184.

Hart, K. 1986. 'Heads or Tails? Two Sides of the Coin.' Man (new series) 21(4):637-657.

Hart, K. 2000. Money in an Unequal World. London: Texere Publishing Limited.

715

Hitlin, S. and Vaisey, S. 2010. The Sociology of Morality. London: Springer.

Heek, R. 2009. 'Understanding "Gold Farming" and Real-Money Trading as the Intersection of Real and Virtual Economies.' Journal of Virtual Worlds Research. 2(4):4-27.

Ingham, G. 1996. 'Money is a Social Relation.' Review of Social Economy. 4(Winter): 507-529.

Jones, C. 2010. 'Lying, Cheating, and Virtual Relationships.' Global Virtue Ethics Review. 6(1):3-12. 
725 Kaplan, A and Haenlein, M. 2009. 'Consumer use and business potential of virtual worlds: The case of Second Life.' International Journal of Media Management. 11(1):93-101.

Kurzweil, R. 2006. The Singularity is Near. New York: Penguin.

730 Lamont, M. 1992. Money, Morals, and Manners. Chicago: University of Chicago Press.

Levenstein, H. 2003. Revolution at the Table. Berkeley: University of California Press.

Luck, M. 2009a. 'Crashing a Virtual Funeral.' Journal of Information, Comunication \& Ethics in Society. 735 7(4):280-285.

Luck, M. 2009b. 'The gamer's dilemma.' Ethics and Information Technology. 11(1):33-6.

Martey, R and Consalvo, M. 2011. 'Performing the Looking-glass Self.' Popular Communication. 740 9(2):165-180.

Martin, J. 2012. 'Consumption without currency' in M. Molesworth and J. Denegri-Knott (eds.) Digital Virtual Consumption, pp.193-206. London: Routledge.

745 Marx, K. [1867]1906. Capital. Vol. III. Trans. Moore, S. and Aveling, E. New York: Modern Library. Massengill, R. and Reynolds, A. 2010. 'Moral Discourse in Economic Contexts', in S. Hitlin and S. Vaisey (eds.) The Sociology of Morality, pp.485-502. London: Springer.

750 Metanomics. 2007a. 'Second Life's Economic Architecture.' November 5. Transcript accessible at: http://www.slideshare.net/WeAreRemedy/110507-second-lifes-economic-architecture-metanomicstranscript Accessed April 2013.

Metanomics. 2007b. 'Virtual Finance.' November 20. Transcript accessible at:

755 http://www.slideshare.net/WeAreRemedy/111207-virtual-finance-metanomics-transcript Accessed April 2013.

Micheletti, M. 2003. Political Virtue and Shopping : Individuals, Consumerism, and Collective Action. London: Palgrave MacMillan.

Nakamura, L. 2009. 'Don't Hate the Player, Hate the Game: The Racialization of Labor in World of Warcraft.' Critical Studies in Media Communication. 26(2):128-144. 
Polillo, S. 2011. 'Money, Moral Authority and the Politics of Creditworthiness.' American Sociological 765 Review. 76(3):437-464.

Powell, C. 2010. 'Four Concepts of Morality', in S. Hitlin and S. Vaisey (eds.) The Sociology of Morality, pp.35-56. London: Springer.

770 Ross, S. forthcoming. 'What is Ambiguous about Ambiguous Goods?' Journal of Consumer Behaviour.

Sayer, A. 2005a. 'Class, Moral Worth and Recognition.' Sociology. 39(5):947-963.

Sayer, A. 2005b. The Moral Significance of Class. Cambridge: Cambridge University Press.

775

Shepherd, T. 2013. Second Life Grid Survey. http://www.gridsurvey.com Accessed July 42013.

Simmel, G. [1907]1978. The Philosophy of Money. Frisby, D and Bottomore, T. (trans.) London: Routledge.

780

Southerton, D. 2002. 'Boundaries of 'Us' and 'Them': Class, Mobility and Identification in a New Town '. Sociology. 36(1):171-193.

Thrift, N and Leyshon, A. 1997. Money/Space. London: Routledge.

785

Weber, M. [1930]2001. The Protestant Ethic and the Spirit of Capitalism. Trans. Talcott Parsons. London: Routledge.

Whitty, M, Young, G and Goodings, L. 2011. 'What I won't do in pixels: Examining the limits of taboo 790 violation in MMORPGs.' Computers in Human Behavior. 27(1):268-275.

Wright, T, Boria, E and Breidenbach, P. 2002. 'Creative Player Actions in FPS Online Video Games.' Game Studies. Accessible at: http://www.gamestudies.org/0202/wright/ Accessed July 202013.

795 Wuthnow, R. 1996. Poor Richard's Principle. Princeton: Princeton University Press.

Young, G. 2013. 'Enacting taboos as a means to an end; but what end?' Ethics and Information Technology. 15(1):13-23.

800 Zelizer, V. 1996. 'Payments and Social Ties.' Sociological Forum. 11(3):481-495. 
Zelizer, V. 1997. The Social Meaning of Money. Princeton: Princeton University Press.

Zelizer, V. 2005. The Purchase of Intimacy. Princeton: Princeton University Press.

805

Zwick, D, Denegri-Knott J and Schroeder , J. 2007. 'The Social Pedagogy of Wall Street: Stock Trading as Political Activism? ' Journal of Consumer Policy. 30(2):177-199. 
Emphasis in original.

ii Residents use SL profiles to assess others' virtual social positions and identities (Beollstorff 2008:184). Profile-stalking, or checking the profiles of people nearby or owners of virtual objects and businesses is normative, especially amongst entrepreneurs. Newer residents are also identifiable by their embodiment(s) and how they interact with others (Martey and Consalvo 2011:173)

iii Business owners previously offered money and prizes for campers to boost traffic to their virtual land, which increased their visibility in the Second Life search engine. This practice is no longer permitted.

iv Transhumanism is a deeply problematic movement whose Orientalised, racist and often sexist tropes are beyond the scope of this article, but it would be remiss not to acknowledge them.

v The intriguing possibility of a tyrannical economic Singularity, resembling HAL-9000 from 2001: A Space Odyssey rather than the popular (mis)interpretation of Adam Smith's benevolent invisible hand, was not considered by IntLibber or other interviewees with similar views. 